\title{
Research on the tourism destination image and sustainable development of off-season ecotourism based on tourists' perception -- A case study of Daoxiang Lake in Beijing
}

\author{
Shi Ran Lin ${ }^{1, a}$, Huan Xi Zhao ${ }^{2, b^{*}}$ \\ ${ }^{1}$ Student in Colledge of Resource Environment and Tourism at Capital Normal University, Beijing, China \\ ${ }^{2}$ Associate professor in Colledge of Resource Environment and Tourism at Capital Normal University, Beijing, China
}

\begin{abstract}
In this paper, we study the question of relationship and influence between tourists' perception and the image of off-season ecotourism destination and sustainable development of tourism, which is based on the web text. Firstly, we analyze the tendency of high-frequency words as tourism perception and customer attitude using the data of network text which is from review websites. Secondly, we study the image perception differences of ecotourism destinations in low and peak seasons through text replacement, perceived category comparison, perceived emotion comparison, and social network and network semantics comparison. Finally, we provide relevant suggestions and opinions on the sustainable development of off-season ecotourism, which is from the aspects of tourism attraction management, tourism publicity and ecological environment protection.
\end{abstract}

\section{Introduction}

China's tourism industry' development is one of the key parts to promote Chinese economic growth. Recently, the ecological environment has been further improved and the infrastructure configuration is more complete due to the continuous development of ecological construction in China. Therefore, ecotourism has played an important role in the development of China's tourism industry and brought great economic benefits. In addition to bringing economic benefits, ecotourism also has high social benefits because of its emphasis on conservation, community participation, and bringing benefits to local communities. Ecotourism has become increasingly popular in the academic filed based on the above analysis.

Researchers take more attention on ecologically sustainable development in the field of ecologies. In the study of sustainable development, it is very important to discuss the factors of time and season. Among these issues, one of the key points is the off and peak season of ecotourism, which will affect the sustainable development of ecotourism ${ }^{[1]}$. The reason is that the tourism resources of seasonal difference and the tourists preference differences cause the problem of unbalanced development, performance for dual fluctuation of tourism attractions and tourism demand ${ }^{[2]}$, traffic jam, the loss of idle resources, the retention of tourists ${ }^{[3]}$ will affect the level of economic development and the imbalance of tourist sources. Firstly, many tourism attractions have a large number of tourists concentrated in the tourism attractions in the peak season, which could cause traffic congestion. Secondly, the scenic tourist flow is too large to decrease of tourism satisfaction. These features may cause the decline of the revisit rate of tourism attractions, the formation of a non-virtuous cycle phenomenon, and affect the sustainable development of tourism attractions. Therefore, in order to study the problem of peak and off seasons in the development of ecotourism, we need to understand the impact of seasonality on the sustainable development of tourism attractions to make good development strategies. Therefore, it is significant for studying exploitation of tourism attractions to paying attention to solve the question of off-season and peak seasons in the aspect of sustainable development of ecotourism scientifically and moderately.

Tourists' demand and the seasonal differences of tourism resources in ecotourism tourism attractions are the two main factors which could affect the ecotourism of off and peak seasons development. In the recent literatures, researchers take more attention on questions of inbound and outbound tourism. ${ }^{[4]}$. Firstly, most of the researchers take the method of T Entropy Weight method and SWOT to analyze seasonality of tourism attractions. ${ }^{[4,6,7,8]}$. Secondly, there are few researchers studying on off-season and peak season of ecotourism from the perspective of network text analysis, tourists by using the method of independent sample $\mathrm{T}$ test and degree centrality analysis. What's more, in recent topics, researchers mainly focus on questionnaire measurement and the construction of an evaluation framework for tourism image perception ${ }^{[9,10]}$. However, there are restricted literatures on perception

\footnotetext{
* Corresponding author: ${ }^{\mathrm{b}}$ zhaohx@cnu.edu.cn

a catherinelin@yeah.net
} 
comparison from the perspective of high-frequency speech category processing based on network text, through using the methods of independent sample t-test and degree centrality analysis. Therefore, in the paper, we analyze the network text to quantify the tourists' perception and tourism destination imagination. Network text analysis as a new means of data mining ${ }^{[12,14]}$, has been widely applied in the quantitative analysis. And its characteristic is objective and systematic ${ }^{[13]}$. Network text analysis mainly focuses on high-frequency word analysis, sentiment analysis and semantic analysis of network text. The content of the analysis comes from a wide range of sources. The main information sources of tourism network text analysis are official websites and travel agency websites ${ }^{[13]}$. This paper takes Beijing ecological tourism attraction of Daoxiang Lake as an example, which is from the perspective of tourists and using the method of network text analysis to get relevant conclusions. Furthermore, we analyze the tourists' perception in the peak season and off-season of ecotourism attractions, and compare and summarize the characteristics of tourists' perception in off-season and peak seasons by using the analysis methods of high-frequency word category processing, independent sample $\mathrm{T}$ test and degree centrality analysis. Finally, some available suggestions and prospects of the sustainable development of Daoxiang Lake ecotourism tourism attraction and the development of off-season tourism could be attached to the tourism development.

\section{Materials and Methods}

\subsection{Data sources and research methods}

\subsubsection{Data source}

In this paper, tourists' comments on Daoxiang Lake are collected from Dianping.com, a relatively objective review website with the largest customer range. Firstly, we delete the data of the internet tourists' comments of both off-season and peak season because we need to test the text independent sample. As of December 16, 2020, 1085 comments have been received using the software, Octopus. According to the collected information about Daoxiang Lake and the analysis of tourists' online comments, the peak season is from March to November every year, and the off season is from the last December to the second year February In this paper, we organize the comments into two TXT. texts by season.

\subsubsection{Research methods}

Firstly, we use ROST Content Minin6 software to study vocabulary statistics from three aspects of functional analysis: high-frequency word analysis, social network and semantic analysis, and sentiment analysis in this paper

Secondly, the sample is preprocessed to eliminate the noise information and replace the text.

Thirdly, through the word classification, we can distinguish the peak season and off season and ready to analyze.

\subsubsection{Sample preprocess}

Firstly, we conduct the sample preprocessing, which is in order to avoid word segment and synonym repetition. Secondly, we could elevate the accuracy of lexical classification and availability of analysis results based on first step and.

(1) First, this paper added the word segments of 'Daoxiang Lake' and 'Sujiatuo' to the user file of ROST Content Minin6 software and saved them to avoid the error of word segment recognition.

(2) The filter word list is established in highfreinvalid. TXT to avoid the interference of high-frequency words such as 'le',' di','we', 'but', 'is', 'located', 'one', 'mainly', and 'not much' which are not closely related to the image perception of tourism destination.

(3) We manually deleted the visitor ID, posting time and picture information of the comments, only retained the comment content of the tourists, and deleted the meaningless comments.

(4) Word segmentation, word frequency analysis, social network, semantic network analysis and sentiment analysis were carried out for two TXT.

(5) On the basis of not changing the original meaning of tourists, we replace the same meaning words and sentences in that sample were uniformly (partial replacement relationship is shown in Table 1), and the processed samples were saved as TXT.

Table1. Represents the Substitution Relational Table in Text

\begin{tabular}{|c|c|}
\hline $\begin{array}{c}\text { The original } \\
\text { expression }\end{array}$ & $\begin{array}{c}\text { Replace the } \\
\text { expression }\end{array}$ \\
\hline Play, stroll out & Hang out \\
\hline Hang in the park & Park \\
\hline Attractions & Interesting \\
\hline Fun, amusing & Haidian \\
\hline Haidian district & Parking lot \\
\hline A parking space & Travel \\
\hline Walk around the park & Food and beverage \\
\hline Restaurant & Children \\
\hline Baby & Beijing \\
\hline Beijing city & Countryside \\
\hline Rural & Paddy fields \\
\hline Rice & \\
\hline
\end{tabular}

\section{Results \& Discussion}

\subsection{Comparative analysis of tourism destination image cognition categories}

\author{
3.1.1 Comparative analysis of high-frequency words \\ in tourists' image cognition of Daoxiang Lake in off \\ and peak season
}


In this paper, we partitioned the tourist comments in peak season and off-season of Daoxiang Lake, after deleting the top 300 words which are not closely related to the topic. In combination with the definition of ecotourism and the classification of tourism destination image perception by Wunder $^{[6,7]}$, Ceballos-Lascurain ${ }^{[11]}$, Hector Ceballos ${ }^{[12]}$, $\mathrm{Xu}$ Xiaobo, Chong Xiaoxiao ${ }^{[13]}$ and Zhao Lei ${ }^{[12]}$, Cheng Shanshan, Xia Zancai ${ }^{[17]}$, the high-frequency words and word frequency of the top ranking were extracted, and the high-frequency words of tourism destination image cognition of Daoxiang Lake were divided into 5 main categories and 10 sub-categories, as shown in Appendix 1 and Appendix 2. To continue the relevant quantitative analysis, reviews of tourists who travel in both peak and off-season have been excluded. There are great differences in tourists' perception of Daoxiang Lake in the off and peak season from the list of high-frequency words and the proportion of high-frequency words.

First of all, in terms of overall perception, tourists' overall perception in peak season $(25.42 \%)$ is towards to the feeling of region, traffic accessibility and overall tourism experience. However, tourists in off-season (26.24\%) also associate Daoxiang Lake with the Summer Palace, a famous tourism attraction in Beijing, in their overall perception, there are not tendency towards to some special aspects. Through retrospective comments, we can find that, on one hand, many tourists choose Daoxiang Lake for dining after visiting the Summer Palace because of closer distance between the two places. On the other hand, tourists may visit Daoxiang Lake specially because it is in the place of the Summer Palace. The main reason is that the off-season tourism attraction is less crowded, so tourists have more time and energy to perceive the tourism attraction.

Secondly, in the category of tourism resources, reviews from tourists to resource-based attractions in peak season $(11.56 \%)$ relate to the landscape, such as 'reed', 'bloom' and so on. Travelers (17.76\%) reviews are more about the winter scenery in off-season, such as "ice surface" and "frozen". In the artificial attraction, there are rich experiences for tourists in peak season significantly, and a great decrease in artificial tourism in the off-season. Finally, the result is that many tourists are dissatisfied with the noisy and overcrowded artificial tourism in the peak season.

Thirdly, in the category of ecological environment, the proportion of high frequency words of difference is bigger. The peak season tourists are dissatisfied with the natural environment $(11.56 \%)$ of the comments: 'disappointed', 'mosquito', etc., while off-season comments $(15.37 \%)$, dissatisfaction with comments is less. There are more positive comments in peak season: 'holy land', 'cool', 'bloom'. At the same time, there are also some off-season winter travelers commenting: 'wilderness'. On the human environment perception, peak season tourist experience $(8.48 \%)$ is varied, off-season tourist perception $(3.75 \%)$ is concentrated on the 'happiness', 'quiet'. The proportion of human environment perception is different in peak and off seasons, which shows that due to the development of various business activities in the peak season, tourists' perception is more diverse. However, the tourists' perception is not obvious in off season, because that they could enjoy the less activities and see less cultural landscape.

Fourthly, in the recreation condition category, the more travel accommodations and the entertainment facilities are attaching to the peak season. For instance, the outdoor wedding activities for taking wedding photos are mainly concentrated in the peak season. During the off-season, the weather is cold most of the time $(3.26 \%)$, so there are fewer tourists for outdoor weddings. Moreover, fishing and camping activities are also similar to wedding activities, which are greatly restricted by climate, and shows great differences in the comparison of low and peak seasons. In the tourist crowds, the leisure tourists are the major part in off-season period of the tourist types $(8.05 \%)$, Therefore, it is possible to obtain the conclusion that the surrounding resident may enjoy the leisure time after busy works. And because there are fewer tourists in the offseason, residents can take walks and do other activities, In the peak season, there are fewer activities for the purpose of walking (7.4\%) due to the high number of tourists and recreational activities. In peak season, there are fewer activities for the purpose of walking due to the large number of tourists and recreational activities. In terms of travel time, more tourists choose to travel in the May Day and National Day holidays in the peak season, while those in the off-season are mainly on weekends. There are also tourists who travel after rain and snow to enjoy the scenery. Tourists in the off-season also compared their feeling with that in summer.

Finally, in the management of tourism attractions, there are diverse tourists' perceptions in the peak season $(14.29 \%)$, which is reflected in the perception of tourism attractions' reservation, parking, free tickets and facilities. However, tourists' perception (10.14\%) is less diverse, in the off-season, just greening aspect.

\subsubsection{Analysis of differences in tourism perception in peak and off-season}

In order to quantitatively compare the differences of tourists' perception of the image of Daoxiang Lake in peak season and low season. In this paper, we use the software of SPSS to make the independent sample t-test on the high-frequency word category which could see in table 2 . The tourists' perception of tourist groups and tourist services in the off-peak season of Daoxiang Lake is not significantly different. There are obvious differences in tourists' perception in terms of overall perception, tourism resources, ecological environment perception, recreational status and tourism attraction management. 
Table2. T-test Results of Independent Samples

\begin{tabular}{|c|c|c|c|c|c|c|}
\hline \multirow{2}{*}{$\begin{array}{l}\text { The main } \\
\text { categories }\end{array}$} & \multirow{2}{*}{$\begin{array}{l}\text { The second } \\
\text { categoryies }\end{array}$} & \multicolumn{2}{|c|}{$\begin{array}{c}\text { Levene test of variance } \\
\text { equation }\end{array}$} & \multicolumn{3}{|c|}{$T$ test for the mean value equation } \\
\hline & & $\mathrm{F}$ & Sig. & $\mathrm{t}$ & Df & Sig.(double side) \\
\hline \multicolumn{2}{|c|}{ The overall perception } & 13.642 & 0.000 & 3.539 & 39 & 0.001 \\
\hline \multirow[t]{2}{*}{ Tourism resources } & $\begin{array}{c}\text { Resource-based } \\
\text { attraction }\end{array}$ & 12.937 & 0.001 & 3.015 & 61 & 0.004 \\
\hline & Artificial attraction & 14.358 & 1.000 & 3.476 & 46 & 0.001 \\
\hline $\begin{array}{l}\text { Feeling of } \\
\text { ecological } \\
\text { environment }\end{array}$ & $\begin{array}{l}\text { Natural environment } \\
\text { perception } \\
\text { Feeling of Humanistic } \\
\text { Environment }\end{array}$ & 23.356 & 0.000001 & 4.386 & 62 & 0.000046 \\
\hline \multirow{3}{*}{$\begin{array}{l}\text { Recreation } \\
\text { conditions }\end{array}$} & Tourist accommodation & 17.767 & 0.000211 & 4.896 & 30 & 0.000031 \\
\hline & Tourist crowd & 5.498 & 0.028 & 1.577 & 24 & 0.128 \\
\hline & Travel time & 1.471 & 0.239 & 4.770 & 20 & 0.000117 \\
\hline \multirow{2}{*}{$\begin{array}{c}\text { Service } \\
\text { management }\end{array}$} & Tourist service & 21.662 & 0.001 & 2.179 & 9 & 0.57 \\
\hline & $\begin{array}{c}\text { The tourism attractions } \\
\text { management }\end{array}$ & 19.719 & 0.000053 & 4.319 & 48 & 0.000078 \\
\hline
\end{tabular}

\subsection{Contrastive analysis of tourists' image perception emotion in tourism destination}

According to the results of Table $3 \& 4$, the positive emotions of tourists in peak season of Daoxiang Lake $(84.18 \%)$ are lower than those in off-season $(89.78 \%)$. The neutral mood of tourists $(3.74 \%)$ is slightly higher than it in off-season $(1.46 \%)$. In terms of negative emotions, in the peak season of Daoxiang Lake, 110 comments from tourists express their dissatisfaction, accounting for $12.09 \%$. However, in the off-season of Daoxiang Lake, the negative mood of tourists account for $8.76 \%$. In the statistical results of emotion segmentation, tourists have the largest proportion of highly positive emotions, the overall proportion of highly negative emotions is small, however, the overall proportion of neutral emotions is the smallest.

Table3. Statistical Results of Emotional Distribution in Peak Season of Daoxiang Lake

\begin{tabular}{|c|c|c|}
\hline $\begin{array}{c}\text { Emotion types } \\
\text { and statistical } \\
\text { results }\end{array}$ & Total number & Accounted \\
\hline Positive emotions & 766 & $84.18 \%$ \\
\hline Neutral emotional & 34 & $3.74 \%$ \\
\hline Negative emotions & 110 & $12.09 \%$ \\
\hline $\begin{array}{c}\text { Sectional statistics } \\
\text { of positive }\end{array}$ & & \\
emotions & 179 & $19.67 \%$ \\
general (0-10) & 191 & $20.99 \%$ \\
moderate (10- & 396 & $43.52 \%$ \\
20) & & \\
highly (above & & \\
20) & & \\
\hline
\end{tabular}

\begin{tabular}{|c|c|c|}
\hline $\begin{array}{c}\text { Sectional statistics } \\
\text { of negative } \\
\text { emotions }\end{array}$ & & \\
General(-10-0) & 74 & $8.13 \%$ \\
Moderate(-20- & 22 & $2.42 \%$ \\
$10)$ & 6 & $0.66 \%$ \\
Highly(below-20) & & \\
\hline
\end{tabular}

Table4. Statistical Results of Emotional Distribution in Daoxiang Lake in Off-season

\begin{tabular}{|c|c|c|}
\hline $\begin{array}{c}\text { Emotion types and } \\
\text { statistical results }\end{array}$ & Total number & Accounted \\
\hline Positive emotions & 123 & $89.78 \%$ \\
\hline Neutral emotional & 2 & $1.46 \%$ \\
\hline Negative emotions & 12 & $8.76 \%$ \\
\hline $\begin{array}{c}\text { Sectional statistics of } \\
\text { positive emotions }\end{array}$ & & \\
general (0-10) & 39 & $28.47 \%$ \\
moderate (10- & 33 & $24.09 \%$ \\
20) & 51 & $37.23 \%$ \\
highly (above 20) & & \\
\hline Sectional statistics of & & \\
negative emotions & & \\
General(-10-0) & 8 & $5.84 \%$ \\
Moderate(-20--10) & 2 & $1.46 \%$ \\
Highly(below-20) & 0 & $0.00 \%$ \\
\hline
\end{tabular}

In general, tourists' overall emotional perception of Daoxiang Lake is positive in the peak season, while neutral and negative emotions are relatively small. Then, the emotional intensity of positive emotions is relatively higher, but the emotional intensity of negative emotions is dominated by general emotions, and there are few highly negative emotions. In addition, the results show that most tourists are satisfied with the tourism experience of Daoxiang Lake in the off season. In contrast, the overall emotional experience of tourists to Daoxiang Lake in off 
season is better than that in peak season.

The reason is that the negative emotions of tourists in peak season is mainly affected by the environmental conditions of scenic resource attractions and the dissatisfaction of payment management. They commented: 'The hotel has occupied by most of the area and the water of the lake is dirty ' Everything in it is paid! Mess!' 'a lot more parking spaces, but not enough to stop, children's park occupies large parts, a little noisy' 'have been playing loud music' 'management does not reach the designated position' 'narrow road, the more people, poor environment', "smelly water, there are charges of tourist facilities', and so on.

However, the parking space management in the tourism attraction is good, which wins the high praise of most tourists: 'There are lots of parking spaces, don't worry about it, and they're free'. The difference is that the off-season complaints at Daoxiang Lake stem from complaints about the winter scenery: 'There is no scenery in winter.'

Finally, through the difference of tourism perceived emotions, we may find that the negative emotions in the off-season are less than that in the peak season. Therefore, the overall emotional experience of tourists of the off season tour of Daoxiang Lake is better to explain than that in the peak season.

\subsection{Comparative analysis of semantic network of tourists' tourism destination image perception}

\subsubsection{Comparative analysis of semantic network}

Semantic network diagram reflects the hierarchical structure relationship of tourists' perception elements ${ }^{[19]}$. Therefore, we use semantic network diagram to judge the relationship between the perception elements, which is in order to find out the concerned by tourists in the off and peak season. For this method, the words are linked by different density lines, and the higher frequency of common occurrence have the higher density lines.

In the semantic network of peak season and low season of Daoxiang Lake (Figures 1 and 2), high-frequency words such as 'park', 'Daoxiang Lake', 'hotel', 'children', 'play' and 'hotel' are important central nodes of network semantics, these constitute the core perception of the tourist's image of the destination. The peripheral words represented by core perception spread outward, and the closer the distance to the central node words is, the closer the relationship between them is.

Through the semantic web, the tourists' perception of Daoxiang Lake is divided into 'core perception, expectation perception and potential perception'. It reflects the structure of the attraction system of the whole tourism destination and the perception image of tourists.

Taking the core high-frequency word 'Daoxiang Lake' as an example, the peak season of Daoxiang Lake peripheral high frequency words 'free', 'hotel', 'place', 'parking', 'wetland', 'animal', 'lotus', as well as the peripheral high-frequency words 'parking lot', 'kilometer', 'Beijing', 'travel' and 'fit' of the word 'Daoxiang Lake' in the off-season of Daoxiang Lake reflect the tourists' perception of the management and tourism resources of Daoxiang Lake tourism attraction. However, tourists' perception of the image of Daoxiang Lake in the offseason is not as strong as that in the peak season.

On the one hand, expectation perception consists of words such as 'catering', 'facilities', 'amusement park', 'ticket', 'charge', and 'parking lot', which is the perception of tourists on tourism services in tourism attractions. On the other hand, potential perceived words include 'convenience', 'area', 'weather', 'Beijing' and 'Haidian', etc., which reflect tourists' perception of tourism attraction management and location.

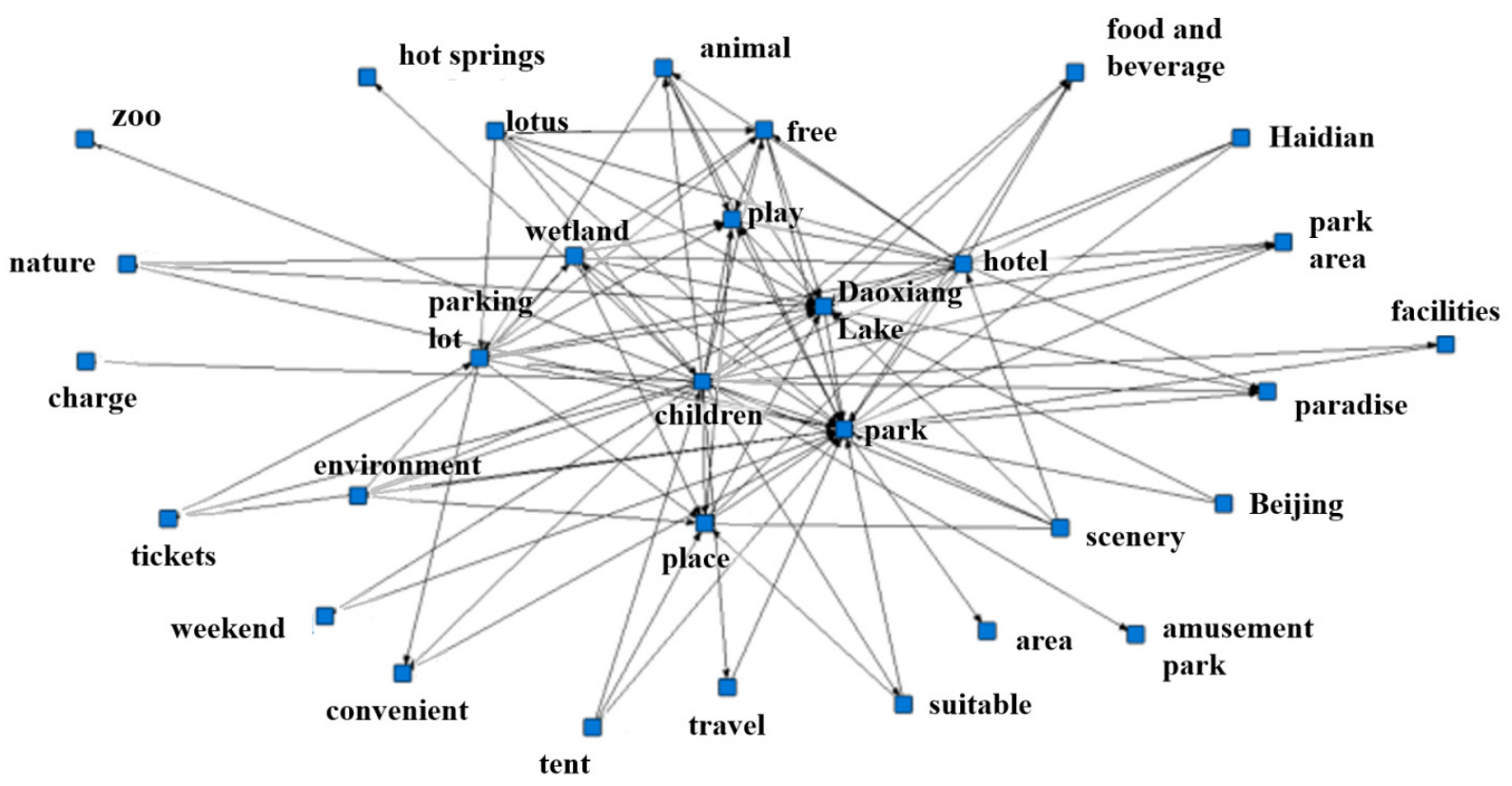

Fig 1. Semantic Network Diagram of Peak Season in Daoxiang Lake 


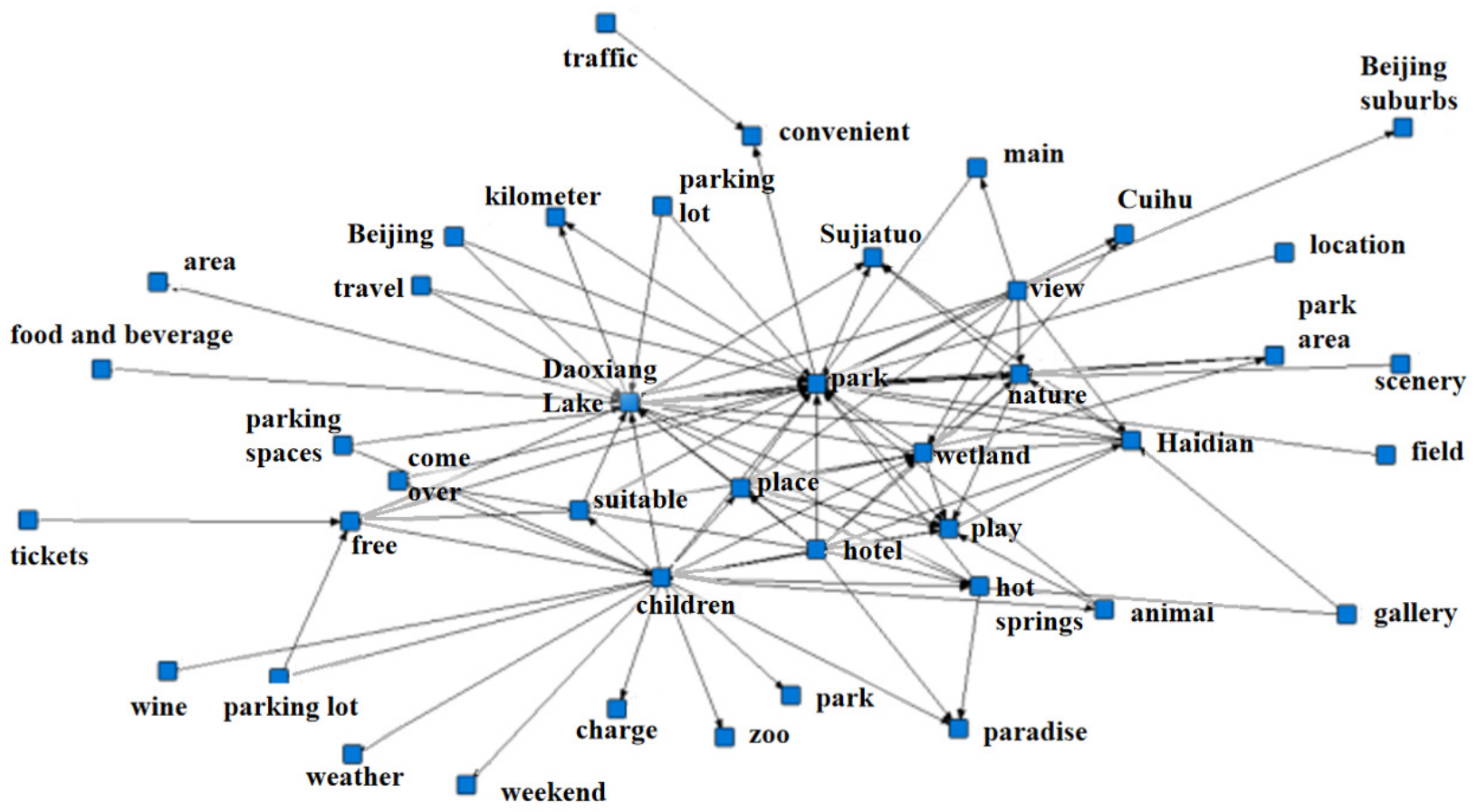

Fig 2. Semantic Network Diagram of Off-season in Daoxiang Lake

The core perception of tourists in the off-season and peak season is the main feature and function of Daoxiang Lake, which could reflect the impression of tourists on the characteristics of tourism attractions. Firstly, expectation perception reflects tourists' deep demand for tourism attraction services and different tourism attractions of Daoxiang Lake in off-season and peak season. Secondly, potential perception reflects the differences between offseason and peak season in Daoxiang Lake.

We can obtain the conclusions from Figure 1 and Figure 2 that there are lots of word described about the evaluation of tourism resources in the off season than that in peak season, which indicates that tourists have time to experience the tourism attractions and have less perception of the tourism attraction management due to the small flow of people in off-season.

The semantic network of Daoxiang Lake in peak season has higher frequents for the tourism attraction management evaluation than that in off-season, which indicates that tourists pay more attention to the infrastructure and tourism attraction management. Furthermore, we go back to the original text, the comments on infrastructure and tourism attraction management are mainly negative, that emotions reflect tourists' dissatisfaction about tourism attraction management and overcrowding.

\subsubsection{Analysis of degree centrality}

In this part, we use numerical analysis to identify the core of Daoxiang Lake off-peak season by using four methods to define the core status of nodes in the network from the centrality analysis of social network, the methods include: degree centrality, between necessity, closeness centrality and eigenvector centrality ${ }^{[21]}$.

In this paper, we use the degree centrality method to quantify the index of centrality of high frequency feature words because that the degree centrality method is the most direct metric to describe node centrality in network analysis, the higher the degree centrality of a node, the more important it is in the network ${ }^{[22]}$. Specific index has absolute point degree centrality and relative point degree centrality.

Table5. Point Degree and Center Degree of High-frequency Feature Words in Daoxiang Lake in Off-peak Season

\begin{tabular}{|c|c|c|c|c|c|}
\hline Daoxiang Lake peak season feature words & degree & Nrm degree & $\begin{array}{c}\text { Daoxiang Lake off- } \\
\text { season feature words }\end{array}$ & degree & Nrm degree \\
\hline Children & & & Park & 317.00 & 7.284 \\
\hline park & 2252.00 & 8.409 & Daoxiang Lake & 215.00 & 4.940 \\
\hline Daoxiang lake & 2248.00 & 8.394 & Children & 199.00 & 4.573 \\
\hline Hotel & 1488.00 & 5.556 & Wetland & 140.00 & 3.217 \\
\hline Wetland & 988.00 & 3.689 & Hotel & 112.00 & 2.574 \\
\hline Parking & 793.00 & 2.961 & Haidian & 92.00 & 2.114 \\
\hline Place & 783.00 & 2.924 & Nature & 91.00 & 2.091 \\
\hline $\begin{array}{c}\text { Hang } \\
\text { out }\end{array}$ & 690.00 & 2.577 & Hang out & 75.00 & 1.723 \\
\hline
\end{tabular}




\begin{tabular}{|c|c|c|c|c|c|}
\hline Free & 545.00 & 2.035 & Suitable & 67.00 & 1.540 \\
\hline Animal & 362.00 & 1.352 & Place & 63.00 & 1.448 \\
\hline Lotus & 338.00 & 1.262 & Scenery & 63.00 & 1.448 \\
\hline The environment & 316.00 & 1.180 & Hot spring & 63.00 & 1.448 \\
\hline & & & & & \\
\hline Paradise & 294.00 & 1.098 & Free & 46.00 & 1.057 \\
\hline Park & 282.00 & 1.053 & Sujiatuo & 37.00 & 0.850 \\
\hline Scenery & 275.00 & 1.027 & Paradise & 27.00 & 0.620 \\
\hline Nature & 233.00 & 0.870 & Come over & 24.00 & 0.551 \\
\hline Food and beverage & 232.00 & 0.866 & Animal & 23.00 & 0.528 \\
\hline Suitable & 188.00 & 0.702 & Park & 22.00 & 0.506 \\
\hline Haidian & 172.00 & 0.642 & Covenient & 15.00 & 0.345 \\
\hline Weeken & 167.00 & 0.624 & Cuihu & 14.00 & 0.322 \\
\hline Ticket & 163.00 & 0.609 & Beijing & 14.00 & 0.322 \\
\hline
\end{tabular}

In Table 5, the relative point degree center degree of children, park and Daoxiang Lake is $>4$, which is located in the center of the whole network. Firstly, they are the core feature words and the core contents of tourists' experience and perception in the peak season of Daoxiang Lake. Moreover, the words followed by hotels, wetlands, parking, places, play, and free, which are the second core of the network. However, animals, lotus, environment, park, park, scenery, located in the periphery of the network. The rest of the words are distributed in the outermost layer of the network, which are the further development and enrichment of the core words and sub-core words.

The relative point degree center degree of Daoxiang Lake Park, Daoxiang Lake and children $>4$, which is located in the center of the whole network, the words are the core feature words and the core contents of tourists' experience and perception during the off season of Daoxiang Lake. They are followed by wetlands, hotels, Haidian and nature, which are the second core of the network. And then, play, fit, place, scenery, hot spring, free, locate on the periphery of the network. The rest of the words are distributed in the outermost layer of the network, which are the further development and enrichment of the core words and sub-core words.

By making the comparison, the peak season feature words can reflect the difference in tourists' perception of Daoxiang Lake begins with the vocabulary at the sub-core position. In the peak season of Daoxiang Lake, tourists' perception of the situation is biased towards tourism resources and infrastructure conditions. But in the offseason of Daoxiang Lake, tourists' perceived intensity of infrastructure was significantly reduced. It can be seen that due to the decrease of the number of tourists in the offseason, the parking space and crowding degree of Daoxiang Lake have been significantly reduced. So that tourists can experience tourism resources more directly without paying too much attention to the state of infrastructure and scenic services.

The words in Table 5 locate in the periphery of the network in the off season is greatly different with the peak season using the method of centrality analysis.

In the peak season of Daoxiang Lake, tourists' perception is mainly about tourism resources, but there are few feeling words to describe tourism resources. The peripheral words of the off season of Daoxiang Lake contain not only the words of tourism resources, but also the descriptive words used by tourists for their feelings of tourism resources. It shows that in the off-season, because tourists do not have to spend much energy to consider matters other than the experience of tourism resources in the tourism attraction, tourists can have more time and energy to experience and enjoy the tour of Daoxiang Lake.

\section{Conclusions}

\subsection{Conclusions}

In this paper, we study the tourists' perception by using the methods of high-frequency word analysis, independent sample T-test, sentiment analysis, social network, semantic network analysis and degree centrality analysis. In addition, we compare the tourists' perception in the offseason and peak seasons of Daoxiang Lake tourism attraction. As the results, the tourists' perception of Daoxiang Lake tourism attraction is concluded, and the conclusions have the significance of innovation, research and development.

By using the methods of independent sample T-test and sentiment analysis, we could give the conclusions: first of all, there are obvious differences in tourists' perception in terms of overall perception, tourism resources, ecological environment perception, recreational status and tourism attraction management. What's more, the tourists' perception in Daoxiang Lake have better emotion about the most of the part of attractions in off season than that in peak season after sentiment analysis. Most tourists are satisfied with the tourism experience of Daoxiang Lake in the off season. In addition, the negative emotions in the off season are less than that in the peak season.

For the aspects of using social network and degree centrality analysis, we can find out that tourists' perception is biased towards tourism resources and infrastructure conditions. But in the off-season of Daoxiang Lake, tourists' perceived intensity of infrastructure was 
significantly reduced. Furthermore, in the peak season of Daoxiang Lake, tourists' perception is mainly about tourism resources, there are few feeling words to describe tourism resources. While in the off season of Daoxiang Lake, comments contain not only the words of tourism resources, but also the descriptive words used by tourists for their feelings of tourism resources.

Therefore, we give sustainable development suggestions for the ecotourism in Daoxiang Lake and it has significance to support the development of off season tourism.

\subsection{Development Suggestions}

Based on the conclusions, the following suggestions are made for the sustainable development of Daoxiang Lake from the perspectives of developing off-season tourism, ecological environment, tourism attraction management and publicity.

\subsubsection{Develop off-season tourism}

By analyzing the tourists' perception of Daoxiang Lake through the network text, we find that the tourists' comments on Daoxiang Lake in the off-season travel have a highly positive mood, and the high frequency comments are mainly positive comments, tourists believed that the atmosphere is quiet and comfortable.

At the same time, the comments showed tourists' dissatisfaction with the management and cultural environment of some tourism attractions during peak season. The relatively large proportion of negative emotions indicates that the unbalanced tourism development in the off and peak season of Daoxiang Lake may affect the ecological environment of Daoxiang Lake and the surrounding catering operation. And it gives the results which is in large fluctuations in the operation status and unbalanced environmental governance, which further reduces the satisfaction of tourists and affects the sustainable development of Daoxiang Lake.

The development of off-season tourism can help to solve the problem of tourism seasonality, reduce the negative impact of seasonality on the ecology and economy of the tourism destination, and improve the tourism experience. In winter, innovative activities can alleviate the shortage of resource-based attractions and make full use of the seasonal tourism resources of Daoxiang Lake to meet the needs of tourists.

Firstly, relevant seasonal activities can be added to attract tourists in the off-season so as to increase the income of relevant merchants in the off-season and balance the price difference between the off-season and the peak season.

Secondly, some comments said that the peak season activities are too dense, with a large number of people and noise. Therefore, the Daoxiang Lake needs to carry out reasonable and scientific development plans in the busy season, and moderately carry out the development plans of the amusement park.

Thirdly, it can create a bad experience for tourists if large tourists are populating in the tourism. So when necessary, the operating units can charge tickets without free entry to Daoxiang Lake Park to control the tourist flow, enhance the enthusiasm of tourists' perception, and promote the sustainable tourism development of Daoxiang Lake area.

\subsubsection{Improve the quality of ecological environment}

In the category list of tourist comments and high frequency words, many tourists commented on the bad smell and poor quality of the lake in summer. Daoxiang Lake, as an ecotourism area, should pay special attention to the protection of the ecological system.

Firstly, we need to protect the water resources and check it quality frequently, and tourists should be urged to establish protection awareness by broadcasting propaganda and setting up indicators. Secondly, the pollution situation of the surrounding businesses should be remedied, and it is forbidden to discharge at will. The sewage discharge standards should be improved, and the implementation should be supervised. The merchants who do not follow the relevant provisions should be fined, so as to ensure the good quality of water in Daoxiang Lake.

According to the comments, most tourists visit Daoxiang Lake because of good ecological environment and closely range.. Daoxiang Lake and its rice and hot springs are important tourism attractions to attract tourists. Only by ensuring the sustainable development of natural tourism resources in Daoxiang Lake, can the sustainable development of Daoxiang Lake be guaranteed.

\subsubsection{Strengthen tourism attraction management and construction}

According to the statistical results of tourists' emotion distribution, the proportion of negative evaluation in Daoxiang Lake area is higher than that of neutral evaluation. Tracing back to the original commentary, it can be seen that tourists have a lot of dissatisfaction with the management of tourism attractions. Therefore, the tourism attractions needs to do the following things.

Firstly, tourism attractions should reasonably arrange the management and construction of tourism attractions, improve the quality of infrastructure and services, and ensure the improvement of infrastructure.

Secondly, the tourism attractions should manage the activities that disturb the people in the park, keep nice service attitude, as well as do a good job in the management and construction of Daoxiang Lake tourism attraction. And they need to charge appropriate fees, improve the satisfaction of tourists, and get a better perception of tourists' image.

Thirdly, the tourism attractions should do a good job of off-season tourism publicity, so as to improve the quality of online comments, attract more tourists to Daoxiang Lake, and promote the sustainable development of Daoxiang Lake. 


\subsubsection{Improve the utilization rate of off-season tourism resources}

Through the network text analysis, the classification of high-frequency words and the independent sample t-test, the conclusion shows that there are few artificial tourism resources in Daoxiang Lake during the off-season. In order to attract tourists, relevant products could be built according to the resource-based attractions. For example, tourists are more interested in the activities that are on the ice according to high-frequency words. Therefore, in winter, some ice-based activities could be built. In the offseason of spring from January to March, the frequent words of tourists' comments are 'cozy' and 'spring with warm flowers'. Special festivals can be built according to the phenology of planting plants to attract tourists.

\subsubsection{Improve internet advertising and marketing}

As an efficient and objective way to share tourists' perception, relevant websites have also become an important factor affecting the development of a tourism attraction.

Potential, prospective travelers may refer to review websites before making travel decisions. We found that many tourists go to Daoxiang Lake because they see the comments on line, and decide to go there when we analyze the comments. Therefore, tourism attractions should make a better web advertising, pay attention to the cooperation between different industries in the development of offseason tourism, use the 'internet + ' way to publicize their own unique off-season tourism resources to attract tourists, get praise, improve the rate of revisit, and form a virtuous cycle. At the same time, tourism advertising should be carried out in the off-season of tourism to deepen the memory and impression of tourists to the tourism attraction, and remind tourism consumers to keep the memory of Daoxiang Lake tourism attraction and its products (services) at any time.

\subsubsection{Make a classification of tourism scientifically}

Daoxiang Lake view can classify tourists according to behavioral features, so that the sub-market may have similar consumption characteristics after the classification. As a result, different consumer's groups may enjoy different treatment and marketing strategies.

\section{Acknowledgments}

This paper is one of the stage achievements of the laboratory open fund of College of Resources, Environment and Tourism, Capital Normal University.

\section{Appendix}

\begin{tabular}{|c|c|c|c|c|}
\hline $\begin{array}{l}\text { The main } \\
\text { categories }\end{array}$ & $\begin{array}{l}\text { The second } \\
\text { categories }\end{array}$ & \multicolumn{3}{|c|}{ High frequency words (frequency } \\
\hline \multirow{15}{*}{$\begin{array}{c}\text { Overall Perception } \\
(25.42 \%)\end{array}$} & & Park (612) & $\begin{array}{c}\text { The surrounding } \\
(30)\end{array}$ & Pass by (14) \\
\hline & & Place (277) & Super (31) & Easy to find (12) \\
\hline & & Park area $(151)$ & Worthy（30） & Mini type (12) \\
\hline & & Beijing (97) & Ensemble (29) & Downtown (23) \\
\hline & & Haidian (98) & Next time（24） & Subway（23） \\
\hline & & Travel (97) & $\begin{array}{l}\text { For the time } \\
\text { (23) }\end{array}$ & Countryside (36) \\
\hline & & Feeling (15) & In the park (23) & Roadside (21) \\
\hline & & Hang out (203) & $\begin{array}{c}\text { Beijing suburbs } \\
(17)\end{array}$ & $\begin{array}{l}\text { Public transportation } \\
\text { (12) }\end{array}$ \\
\hline & & Area (77) & Center (17) & Small (38) \\
\hline & & Nearby (54) & Public (16) & Scope (34) \\
\hline & & $\begin{array}{c}\text { Tourism attractions } \\
\text { (75) }\end{array}$ & Specially (14) & Entire (33) \\
\hline & & Destination (43) & Expressly (13) & Tourist (32) \\
\hline & & Overall (41) & Visit (12) & Sujiatuo (32) \\
\hline & & Experience $(40)$ & Wide (12) & Navigation (49) \\
\hline & & all kinds of (39) & expand (12) & Select (38) \\
\hline \multirow{6}{*}{$\begin{array}{c}\text { Tourism resources } \\
(26.35 \%)\end{array}$} & \multirow{6}{*}{$\begin{array}{l}\text { Resource-based attraction } \\
(17.87 \%)\end{array}$} & Daxiang Lake (433) & Cuihu (41) & riverside (21) \\
\hline & & Wetland (275) & $\begin{array}{c}\text { Water } \\
\text { surface38) }\end{array}$ & Blossom (21) \\
\hline & & Animal (173) & $\begin{array}{l}\text { Lake surface } \\
(36)\end{array}$ & Reed (20) \\
\hline & & Lotus（170） & $\begin{array}{l}\text { Paddy fields } \\
\text { (49) }\end{array}$ & Pond (20) \\
\hline & & Air (69) & The lawn (33) & Field (19) \\
\hline & & Riverside (68) & Reservoir (30) & Water area (19) \\
\hline
\end{tabular}




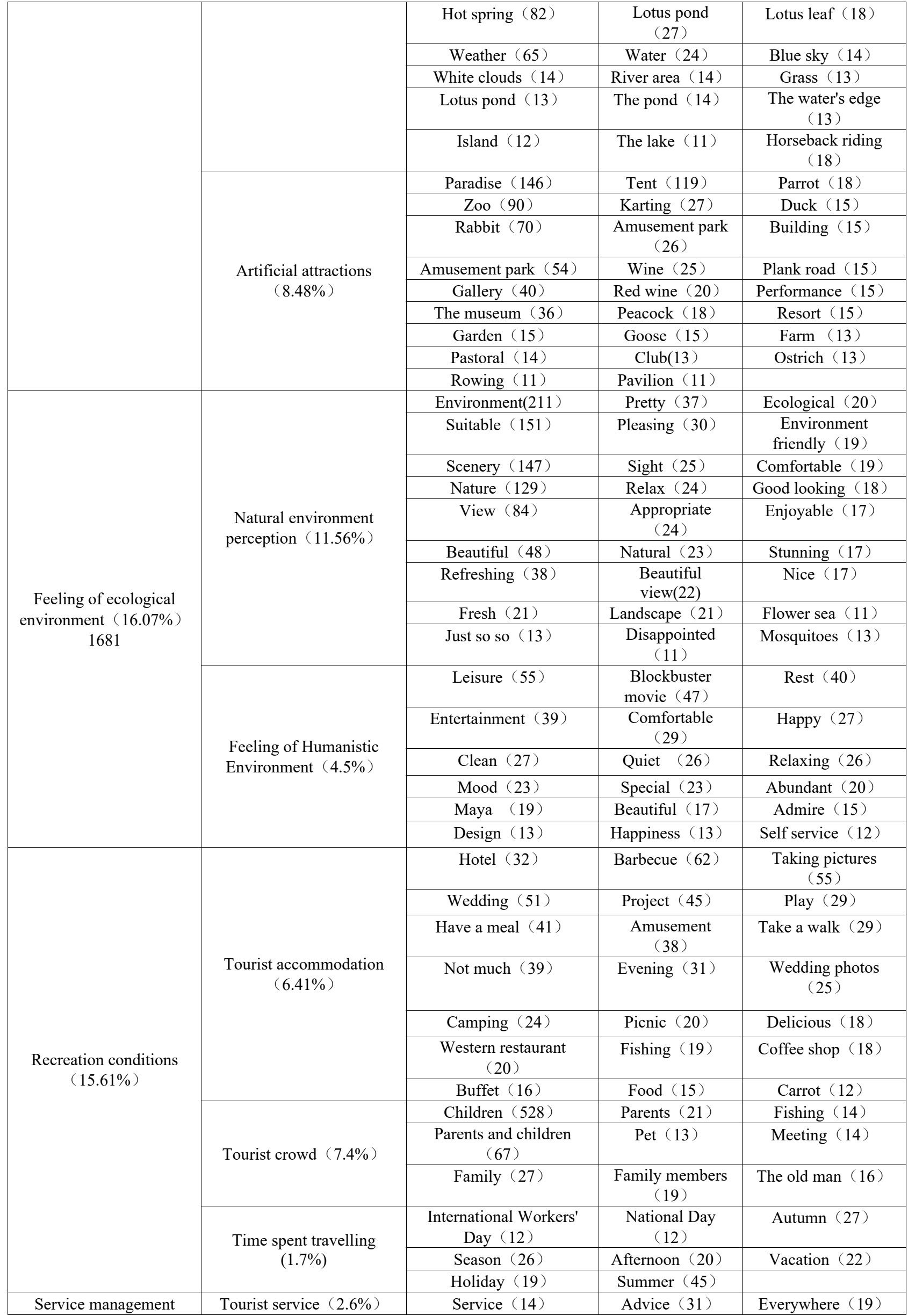




\begin{tabular}{|c|c|c|c|c|}
\hline \multirow[t]{10}{*}{$(3.75 \%)$} & & Time (96) & $\begin{array}{c}\text { Convenient } \\
(96)\end{array}$ & Crowded (17) \\
\hline & \multirow{9}{*}{$\begin{array}{c}\text { Tourism attractions } \\
\text { management }(14.29 \%)\end{array}$} & Many (21) & Personnel (20) & Come over $(56)$ \\
\hline & & Free $(205)$ & Driving (79) & Traffic (42) \\
\hline & & Parking (194) & Charge (71) & Position (40) \\
\hline & & Tickets (106) & Go (62) & $\begin{array}{c}\text { Accommodation } \\
(36)\end{array}$ \\
\hline & & $\begin{array}{c}\text { Food and beverage } \\
(110)\end{array}$ & $\begin{array}{l}\text { Parking lot } \\
(61)\end{array}$ & $\begin{array}{l}\text { Catch up with } \\
\quad(32)\end{array}$ \\
\hline & & Facilities (83) & Go to $(30)$ & $\begin{array}{l}\text { Ancillary facility } \\
\text { (11) }\end{array}$ \\
\hline & & Packing place (55) & Open (29) & Distance (11) \\
\hline & & $\begin{array}{l}\text { To make an appointment } \\
\text { (27) }\end{array}$ & $\begin{array}{l}\text { Parking fee } \\
\quad(20)\end{array}$ & Epidemic (15) \\
\hline & & Door (21) & Not far (18) & Outside (20) \\
\hline
\end{tabular}

\begin{tabular}{|c|c|c|c|c|}
\hline The I & The second & High & quency words (frequ & cy) \\
\hline \multirow{15}{*}{$\begin{array}{l}\text { Overall Perception } \\
(26.24 \%)\end{array}$} & & Park（86） & Outdoor (5) & Happy (4) \\
\hline & & Place (36) & Sujiatuo (11) & $\begin{array}{l}\text { The Summer } \\
\text { Palace (6) }\end{array}$ \\
\hline & & Park area (14) & Surrounding (4) & Pleasant (4) \\
\hline & & Beijing (25) & Overall (3) & Adorable (4) \\
\hline & & Haidian (26) & In the park (2) & Best (3) \\
\hline & & Come over(17) & $\begin{array}{l}\text { Beijing suburbs } \\
\text { (7) }\end{array}$ & Car (3) \\
\hline & & Travel（14） & Subway (5) & Changping (3) \\
\hline & & Hang out (27) & Countryside (7) & Region（3) \\
\hline & & Area (11) & $\begin{array}{l}\text { Public transportation } \\
\text { (4) }\end{array}$ & Absolute (3) \\
\hline & & Nearby（10） & Pass by (6) & Effect (2) \\
\hline & & All kinds of (8) & A place to go (6) & Try (2) \\
\hline & & Churchyard (6) & Color (6) & Accept (2) \\
\hline & & Overall（8) & Around (4) & Public (2) \\
\hline & & Wide (4) & Visit (4) & In the city (2) \\
\hline & & Experience (2) & Casually (4) & $\begin{array}{l}\text { Square kilometers } \\
\text { (2) }\end{array}$ \\
\hline \multirow{15}{*}{$\begin{array}{l}\text { Tourism resources } \\
(26.55 \%)\end{array}$} & \multirow{8}{*}{$\begin{array}{c}\text { Resource-based attraction } \\
(17.76 \%)\end{array}$} & Daxiang Lake (78) & Water (6) & Rowing (11) \\
\hline & & Wetland (45) & Sunlight（6） & Pastoral（14） \\
\hline & & Hot spring (26) & Beside the lake (6) & $\begin{array}{l}\text { West of the lake } \\
\text { (4) }\end{array}$ \\
\hline & & Lotus (5) & $\begin{array}{l}\text { The surface of the } \\
\text { lake (4) }\end{array}$ & $\begin{array}{l}\text { Water surface } \\
\quad(6)\end{array}$ \\
\hline & & Air (8) & Paddy fields (5) & West line (3) \\
\hline & & Riverside (10) & Pond (6) & Grass（3） \\
\hline & & Weather (11) & The field (7) & $\begin{array}{l}\text { East of the lake } \\
(7)\end{array}$ \\
\hline & & Cuihu (11) & Blue sky（2） & River side（5） \\
\hline & \multirow{7}{*}{$\begin{array}{l}\text { Artificial attractions } \\
(8.24 \%)\end{array}$} & Animal (18) & Museum (10) & Waterfowl (3) \\
\hline & & Paradise (15) & Castle (4) & Bubble (3) \\
\hline & & Tent (8) & $\begin{array}{c}\text { Amusement park } \\
\text { (3) }\end{array}$ & $\begin{array}{l}\text { Mallard ducks } \\
\text { (3) }\end{array}$ \\
\hline & & Zoo (11) & Wine (9) & $\begin{array}{l}\text { Red chamber } \\
\text { (3) }\end{array}$ \\
\hline & & Rabbit（5） & Red wine (7) & Game（3） \\
\hline & & Garden (4) & Peacock (2) & $\begin{array}{l}\text { Exhibition hall } \\
\text { (2) }\end{array}$ \\
\hline & & Gallery（13） & Duck（6） & Racecourse（2） \\
\hline \multirow{2}{*}{$\begin{array}{l}\text { Feeling of ecological } \\
\text { environment }(19.11 \%)\end{array}$} & \multirow{2}{*}{$\begin{array}{l}\text { Natural environment } \\
\text { perception }(15.37 \%)\end{array}$} & Environment(17) & Green (2) & Calm (4) \\
\hline & & Suitable (27) & Nice (3) & State (3) \\
\hline
\end{tabular}




\begin{tabular}{|c|c|c|c|c|}
\hline \multirow[t]{10}{*}{1681} & & Scenery (27) & Stunning (7) & $\begin{array}{l}\text { Good looking } \\
\text { (3) }\end{array}$ \\
\hline & & Nature (27) & Breathe (16) & Admire (3) \\
\hline & & Pretty(5) & Cool (16) & Organic (3) \\
\hline & & Beautiful (5) & After rain $(11)$ & $\begin{array}{l}\text { Pretty scenery } \\
\text { (3) }\end{array}$ \\
\hline & & Refreshing (4) & Just so so (2) & Grand (3) \\
\hline & & Natural (4) & Not bad (2) & Comfortable (3) \\
\hline & & Ecological (5) & Spring flowers (4) & \\
\hline & \multirow{3}{*}{$\begin{array}{l}\text { Feeling of Humanistic } \\
\text { Environment }(3.75 \%)\end{array}$} & Leisure (6) & Clean (5) & Quiet（6） \\
\hline & & Happy (7) & Mood (6) & Features (6) \\
\hline & & Enjoyable (5) & & \\
\hline \multirow{10}{*}{$\begin{array}{l}\text { Recreation conditions } \\
\qquad(16.53 \%)\end{array}$} & \multirow{3}{*}{$\begin{array}{l}\text { Tourist accommodation } \\
(3.26 \%)\end{array}$} & Barbecue (8) & Cafe (5) & Hotel（3） \\
\hline & & Taking pictures (7) & $\begin{array}{l}\text { Accommodation } \\
\text { (5) }\end{array}$ & Play（8） \\
\hline & & Have a meal (6) & Western food (3) & Not much (5) \\
\hline & \multirow{4}{*}{ Tourist crowd $(7.4 \%)$} & Children (63) & Meeting (5) & $\begin{array}{c}\text { Gather around } \\
\text { (4) }\end{array}$ \\
\hline & & Friends (8) & Taking photos (7) & Tourists (6) \\
\hline & & Family (9) & Walk around (6) & $\begin{array}{l}\text { Entertainment } \\
\text { (4) }\end{array}$ \\
\hline & & $\begin{array}{l}\text { Family members } \\
\text { (4) }\end{array}$ & Walk (5) & Take a walk (4) \\
\hline & \multirow{3}{*}{$\begin{array}{l}\text { Time spent travelling } \\
(5.23 \%)\end{array}$} & Weekend (22) & Summer (12) & Afternoon (2) \\
\hline & & Spring (4) & $\begin{array}{l}\text { Spring and summer } \\
(5)\end{array}$ & At noon (3) \\
\hline & & Winter (16) & Working days (4) & Autumn (3) \\
\hline \multirow{8}{*}{$\begin{array}{l}\text { Service management } \\
\quad(12.10 \%)\end{array}$} & \multirow{2}{*}{ Tourist service $(1.97 \%)$} & Convenient (14) & Line (7) & Build (3) \\
\hline & & Worthy(5) & In advance (3) & \\
\hline & \multirow{6}{*}{$\begin{array}{c}\text { Tourism attractions } \\
\text { management }(10.14 \%)\end{array}$} & Sufficient (3) & Go in (6) & Outside (2) \\
\hline & & Facilities (8) & Parking lot (11) & Epidemic (3) \\
\hline & & Parking(15) & Traffic（13） & Distance (6) \\
\hline & & Tickets $(8)$ & Location (7) & Exit (6) \\
\hline & & $\begin{array}{l}\text { Food and beverage } \\
\text { (11) }\end{array}$ & Parking places (8) & Greening (4) \\
\hline & & Drive (11) & Open (9) & Species (3) \\
\hline
\end{tabular}

\section{References}

1. Feng X. G., Sun X. D., Yu Q. Y.(2014) Off-season tourism and seasonal balance of tourism: A Review and Implications. J. Travel journal, 1:92-100.

2. Cuccia T., Rizzo I. (2011) Tourism seasonality in cultural destinations: Empirical evidence from Sicily. J. Tourism Management., 32(3):589-595.

3. Cater, Erlet. (2002) Spread and backwash effects in ecotourism: implications for sustainable development. J. International Journal of Sustainable Development, 5(3):265.

4. Chen B. X.,Qiu Z. M.(2017) Community attitudes toward ecotourism development and environmental conservation in nature reserve:a case of Fujian Wuyishan National Nature Reserve, China. J. Journal of Mountain Science,14(07):1405-1418.

5. Cai S. J.(2016) Discussion on out-of-season tourism. J. Shanxi agricultural economy.,6:24-25.

6. Huang H. P.(2015) Seasons and anti-season development strategies of inbound tourism in Shanghai J. Resource development and market.,31(8):1017-1020.

7. Fan.Y. N.(2015) An Analysis of the anti-season tourism and the seasonal balance of tourism. J. Research on Modern State Owned Enterprises., 14:139.

8. Song X., Wang W. G.(2020) Evaluation of linear and nonlinear forecast models for seasonality of inbound Tourism in China. J. Statistics and Decision Making.,36(2):5-10.

9. Pan Y. L., Xu J., Hu S. C., Wen Y., Zhou Q., Yan Q., Zeng J., Gu X. R., Liu Y. Q.(2019) Study on the construction strategy of forest health base based on SWOT and AHP analysis_— Take Lushan National Nature Reserve in Jiangxi Province as an example. J. The forestry Economic,41 (3):40-44+59.

10. Mazanec J. A., Strasser H.(2015) Perceptions-based analysis of tourism products and service providers. J. Journal of Travel Research,45(4):387-401.

11. Cheng J. L.(2011) Study on the mechanism of urban tourism image perception. J. Human 
geography.,26(3):142-146.

12. Ceballos-Lascurain H.(1998) Tourism, ecotourism and protected areas. J. Geographical Journal., 164(3):349.

13. Listed N. A.(1992) Tourists for conservation. interview: Hector Ceballos-Lascurain. J. People \& the Planet., 1(3):28-30.

14. Xu X. B., Zhao L., Liu B. Y., Wu B. H., Zhong L. N.(2015) Perceived characteristics and differentiation of tourist city image in China. J.Geographical research.,,34(07):1367-1379.

15. Zhao Z. B., Dang J.(2011) Study on backpacking tourism behavior in Taibai Mountain based on network text content analysis. J. Human geography.,26(1):134-139.

16. Hou Y., Wu M. L.(2020) A comparative study of tourist tourist image perception based on network text analysis — Take the ancient towns of Luzhi and Nanxun as examples. J. Journal of Chongqing University of Arts and Sciences (Social Science Edition).,39(5):72-82.

17. Wunder S.(2000) Ecotourism and economic incentives. J. Ecological Economics.,32(3):p.465-479.

18. Cheng S.S., Xia Z. C.(2018) A comparative study of tourism image perception in culture-themed tourism attractions based on network text_— Take Shenzhen and Changsha Window of the World as examples. J. Tourism BBS.,11(5):111-123.

19. Zhong X. X.(2018) Research on the image perception of ecotourism destination based on network text analysis__ Take the Yarlung Zangbo Grand Canyon as an example. J. Journal of Wuxi commercial vocational and technical college.,18(5):40-46.

20. Wang Y. M. Wang M. X., Li R.(2015) Research on tourism image perception of Fenghuang ancient town based on network text content analysis. J. Geography and Geographic Information Science.,(1):64-67.

21. Xie H., Zhang Y.(2019) Construction of rural tourism brand culture from the perspective of homesickness appeal - Take Xucun of she county, Anhui province as an example. J. Journal of Chongqing University of Arts and Sciences (Social Science Edition).,(4):1-8.

22. Lin X. B., Guo W. F., Lin K. M.(2020) Study on the $\mathrm{B} \& \mathrm{~B}$ experience of world heritage site based on network text analysis_— take mount Wuyi B\&B as an example. J. Journal of $\mathrm{Xi}$ 'an University of Architecture and Technology (Social Science Edition).,39(04):66-73+87. 